\title{
Blue Bay as a Sub-Satellite Ground for Evaluating Hydrochemical Characteristics in the Shelf Areas of the Crimea
}

\author{
S.I. Kondratev, A.V. Varenik, Yu.L. Vnukov, K.I. Gurov, \\ O.N. Kozlovskaya, E.A. Kotelianets, E.V. Medvedev, N.A. Orekhova, \\ S.V. Svishchev, D.S. Khoruzhiy, S.K. Konovalov
}

Marine Hydrophysical Institute, Russian Academy of Sciences, Sevastopol, Russian Federation e-mail: skondratt@mail.ru

\begin{abstract}
Assessment of state and quality of the sea and ocean surface layer waters resulted from binding the data from satellite images and the results of the simultaneously done in situ measurements is the actual direction of modern complex oceanological studies. Further development of this direction the immediate task of which consists in defining hydrochemical composition of water based on satellite data requires selecting the regions in the Black Sea where in situ measurements of water hydrochemical characteristics can be carried out simultaneously with satellite monitoring of the surface water state. The results of analysis of the hydrochemical characteristics' (main elements of nutrient and carbon cycles) spatial distribution in the Blue Bay waters based on the data of the expeditionary research carried out by Marine Hydrophysical Institute in 2002-2014 are represented. It is shown that this region and the stationary oceanographic platform (SOP) located in its southwestern part constitute a convenient ground for synchronous remote and sub-satellite studies of natural oceanological processes and impact of the coastal anthropogenic pollution sources. The data on hydrochemical characteristics of surface water in the SOP region can be used to study background state of the coastal marine environment as well as influence of intense natural processes (storms and (or) upwellings) upon formation and evolution of hydrochemical and optical structure of surface waters, surface water and atmosphere gas exchange, effect of physical, chemical and biological processes on the sea water quality. Influence of two coastal sources of anthropogenic pollution upon the Blue Bay marine environment was studied using synchronous remote and sub-satellite measurements; the results of these investigations provide additional opportunities for developing and certifying the methods of remote study and monitoring of the coastal marine environment state.
\end{abstract}

Keywords: Blue Bay (Crimea), stationary oceanographic platform, remote study, sub-satellite ground, elements of nutrient cycle, elements of carbon cycle, field data of 2002-2014.

DOI: $10.22449 / 1573-160 X-2016-1-48-59$

(C) 2016, S.I. Kondratyev, A.V. Varenik, Yu.L. Vnukov, K.I. Gurov, O.N. Kozlovskaya,

E.A. Kotelianetz, E.V. Medvedev, N.A. Orekhova, S.V. Svishchev, D.S. Khoruzhiy,

S.K. Konovalov

(C) 2016, Physical Oceanography

Introduction. The entire shelf part of the Black Sea (regardless of the fact which country an economic zone belongs to) is a water area exposed to constant and intensive anthropogenic impact. River runoff control, water exchange violation due to construction of different onshore facilities (e.g. piers), pollution and eutrophication, which arise from the insufficiently treated sewage waters and polluted river water discharge, are the factors of negative effect on coastal water quality. Furthermore, the multipurpose usage of shelf water area (exploitation of military and trade harbors, shipyards and ship repair facilities, fishing and mariculture, tourism, recreation and so on) in the absence of appropriate 
environmental activities has resulted in a sharp deterioration of environmental situation.

The consequences of long-term anthropogenic impact on shelf waters may manifest themselves through the changes of hydrodynamic and hydrological characteristics, transformation of water and bottom sediment hydrochemical structure in the direction of their pollution and creation of technogenically and ecologically dangerous hydrochemical background. The most negative case of hydrochemical water structure change is an occurrence of hypoxic and anoxic conditions [ $1-3]$ that result in regular fish mortality. Deterioration of water quality (waters are one of the most valuable components of the Crimean recreational potential) is also significant by its negative manifestation. At the same time, the location of beaches and recreation zones on the one hand, and anthropogenic sources of pollution on the other, is often uncoordinated and does not meet the basic criteria of spatial planning. The assessments of such pollution source impact on the quality of coastal waters are absent, the monitoring in not performed.

Therefore, the Black Sea shelf monitoring (its main purpose is a study of current hydrological and hydrochemical regime) is the most important environment protection preventive objective for diagnosis and forecast of marine environment ecological state of the entire Black Sea. The estimation of the content of nutrients, carbon cycle and dissolved oxygen elements in the water should be the main direction of shelf water hydrochemical monitoring. These data give an insight of organic substance internal biotransformation in marine ecosystems, basic conditions of their functioning and the processes, which determine many of the characteristics of the seawater quality.

In order to control a hydrochemical composition of coastal waters, a systematic (at least annual) monitoring of all shelf waters, as it has been performed in $60^{\text {th }}-80^{\text {th }}$ of the XX century, is required. However, in recent years only the episodic Black Sea oceanologic research, where hydrochemistry hadn't been always fully represented, was performed.

An estimation of the sea and ocean surface layer state and quality, obtained according to the satellite survey data, and its comparison with the field measurement results (performed at the same period of time) are the actual trends of contemporary oceanographic complex research. The results of current satellite monitoring and the Earth remote sensing are used to determine a content of phytoplankton and total suspended matter content in the surface waters [4, 5], oil pollution [6, 7], intensive phytoplankton bloom [8, 9], assessment of coastal pollution source impact [10].

For the further development of this trend (its immediate goal is to assess a hydrochemical structure of waters by satellite data) it is necessary to determine the Black Sea regions where it would be possible to carry out the field measurements of surface waters hydrochemical characteristics simultaneously with the satellite monitoring.

Thus, we should select a shelf area where it is possible to register an anthropogenic impact by change of hydrochemical characteristics, and at the same time the region must be accessible for carrying out of operative expeditionary works. According to these requirements, the Blue Bay area near Katsiveli village and the stationary oceanographic platform (SOP), located at the south-western edge 
of the Blue Bay, were selected (Fig. 1). The objective of this work is an assessment of this region as a ground for synchronous remote and sub-satellite field research.

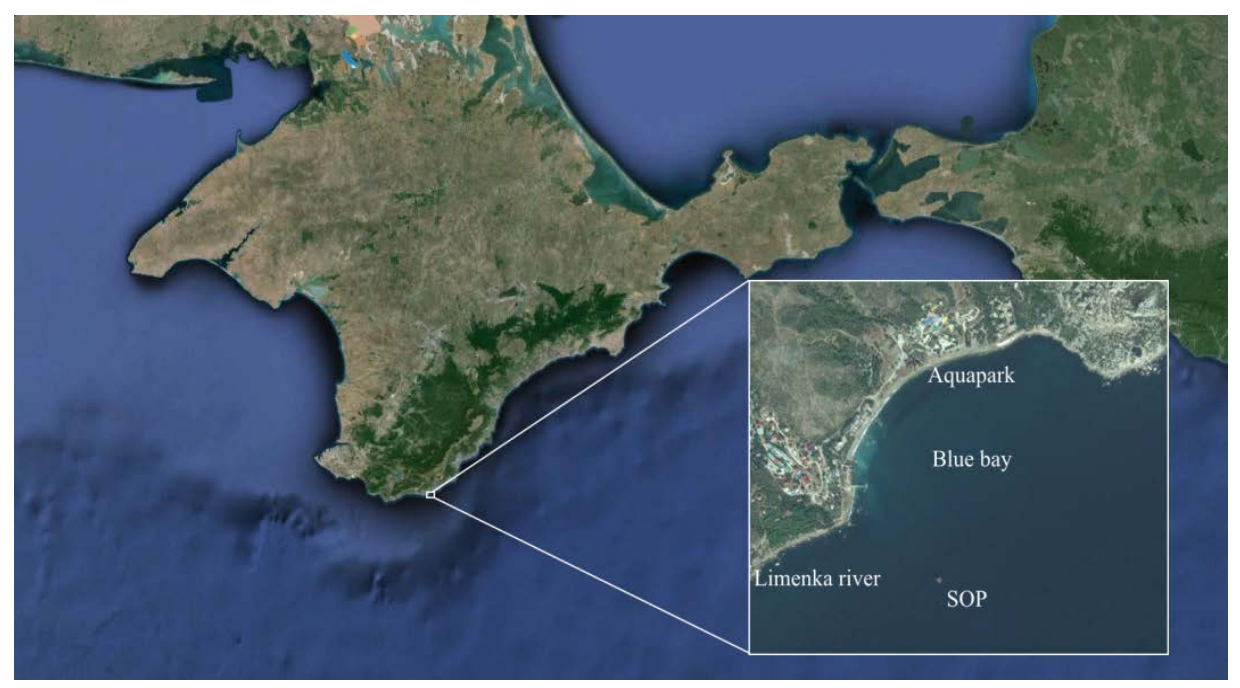

Fig. 1. Blue Bay and the location of anthropogenic sources

Materials and methods. In the given work the results of the research, carried out by Marine Hydrophysical Institute (MHI) at the ground located in the Blue Bay region in September 2002, were used. The seawater samples from surface and nearbottom horizons were collected in this expedition using the STD-probe. In seawater samples the content of oxygen, nutrients (phosphates, silicic acid, the amount of nitrates and nitrites) and the carbonate system ( $\mathrm{pH}$ value, total alkalinity, total inorganic carbon) was determined.

The results of the works performed at SOP by MHI biogeochemistry department in 2009 - 2014 in different hydrological seasons (usually in May, September and in late November) were also used. In this research the collection of water samples at three surface water horizons $-0 ; 0.5$ and $5 \mathrm{~m}$ was carried out by means of submersible pump during $2-3$ weeks at different time of a day (usually at 7:00, 12:00, 18:00 and sometimes, if the upwelling was observed, at 23:00). In case of intensive wind-induced mixing of a surface layer, the collection of samples was performed from two and sometimes one horizon due to storm conditions. The collected samples were immediately frozen in $250 \mathrm{ml}$ plastic containers (these samples were analyzed for content of nutrients in MHI stationary laboratory after they had been brought ashore) or were analyzed for dissolved oxygen and carbon dioxide concentration, values of total alkalinity and $\mathrm{pH}$ directly at the SOP.

In all cases chemical analytical determinations were carried out according to techniques recommended for use upon hydrochemical ocean research [11]. The certified standard samples (governmental standards) developed by STC PhysicoChemical Institute of the National Academy of Sciences of Ukraine were applied for device calibration when using the physicochemical measuring methods and check of analysis results. 
Results and discussion. Hydrochemical study of the Blue Bay waters. The Blue Bay (near Katsiveli village) is situated at a sufficient distance from the Kerch Strait and there is no manifestation of the Azov Sea waters in this region. Propagation of these waters, for example, into the Feodosia Gulf and further to Meganom Cape in December 2006 had been registered by satellite images and was confirmed later by field data of hydrologic-hydrochemical survey [12].

In the coastal region of the Crimea near the Blue Bay powerful industrial or agricultural enterprises are absent. An anthropogenic impact on the water hydrochemical composition of the Bay may be caused only by domestic wastewaters discharged from the shore (Limenka River is a runoff for Katsiveli treatment plants) or at insufficient distance from water line (Aquapark entertainment complex, treatment plants between Alupka and Simeiz) (Fig. 1). It was reliably recorded in the research carried out in 2002 [13, 14]. They indicated that freshwater runoff of Limenka River had a sufficient effect on the distribution in surface layer of silicic acid, and a seawater runoff from the Aquapark affected near-bottom nitrate distribution (Fig. 2). The effect of two abovementioned sources of anthropogenic impact on the Blue Bay coastal ecosystem was further confirmed by hydrobiological research [15].

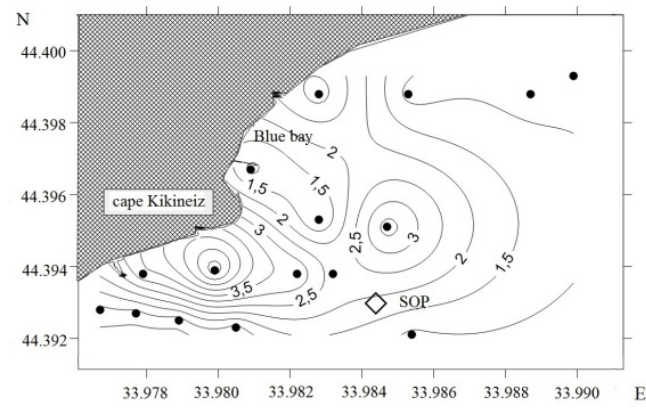

$a$

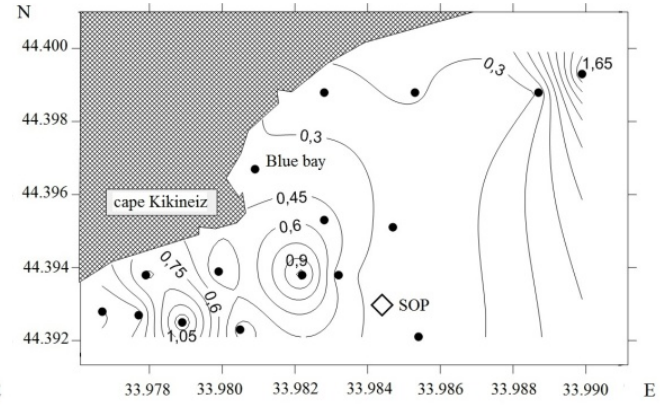

$b$

Fig. 2. Surface layer silicic acid distribution $(\mu \mathrm{M})-a$ and near-bottom distribution of nitrates $(\mu \mathrm{M})-$ $b$ in the Blue Bay coastal waters in September 2002

One could assume that the SOP sufficient distance from the shore $(440 \mathrm{~m})$ excludes the impact of Katsiveli village and Aquapark wastewater on the water characteristics. Thus, when comparing the generalized data of hydrochemical parameter analytical determinations obtained during the coastal expeditions, which had been carried out at the Black Sea in 2006 - 2010 by MHI (the expeditions covered the Black Sea shelf from the Kerch Strait to near-estuary areas of the Danube and the Dnieper [16]), it was shown that characteristics for the SOP area were similar to "background" characteristics for shelf water areas near the Crimea.

Nevertheless, during a more detailed examination of hydro-chemical and hydro-optical research results (the research was performed in the Blue Bay at September 16, 2002) it was found that the oceanographic platform is situated within the zone, which in certain conditions is exposed to a coastal runoff impact. Thus, in addition to inhomogeneous distribution of silicic acid in surficial waters, nitrates in near-bottom waters and water saturation with oxygen (no figure given), 
the increased concentrations of phosphates and nitrites (no figures are given) in the water column, adjacent to the SOP water area, were registered.

Hydrochemical research at the stationary oceanographic platform. While studying a hydrologic-hydrochemical regime of shelf areas, one of the most important goals of contemporary chemical oceanography is a research of physical and biochemical process effect on gas exchange at the air-sea interface, because it is the gas exchange that largely determines the oxygen budget and consumption of carbon dioxide excessive amount by the ocean. Therefore the main goal of studies at the SOP was to obtain the data of regular field observations on oxygen content and vertical distribution and elements of carbon cycle inorganic part $(\mathrm{pH}$, total inorganic carbon and carbon dioxide partial pressure) in $5 \mathrm{~m}$ of water surface layer and atmosphere with simultaneous monitoring of meteorological conditions and hydrological characteristics of the water. Since 2012, a determination of nutrient content was added to these parameters.

As it will be shown below, upwelling, regularly occurring near the Southern Coast of the Crimea (SCC) in spring - summer period, has the greatest effect on the content of all studied hydrochemical components. That is why before the discussion of single components we are to consider the way of upwelling phenomena registration near the SOP by means of field observation data. The upwelling development at the SCC region can be observed by water surface temperature change, obtained by means of satellite data (Fig. 3).

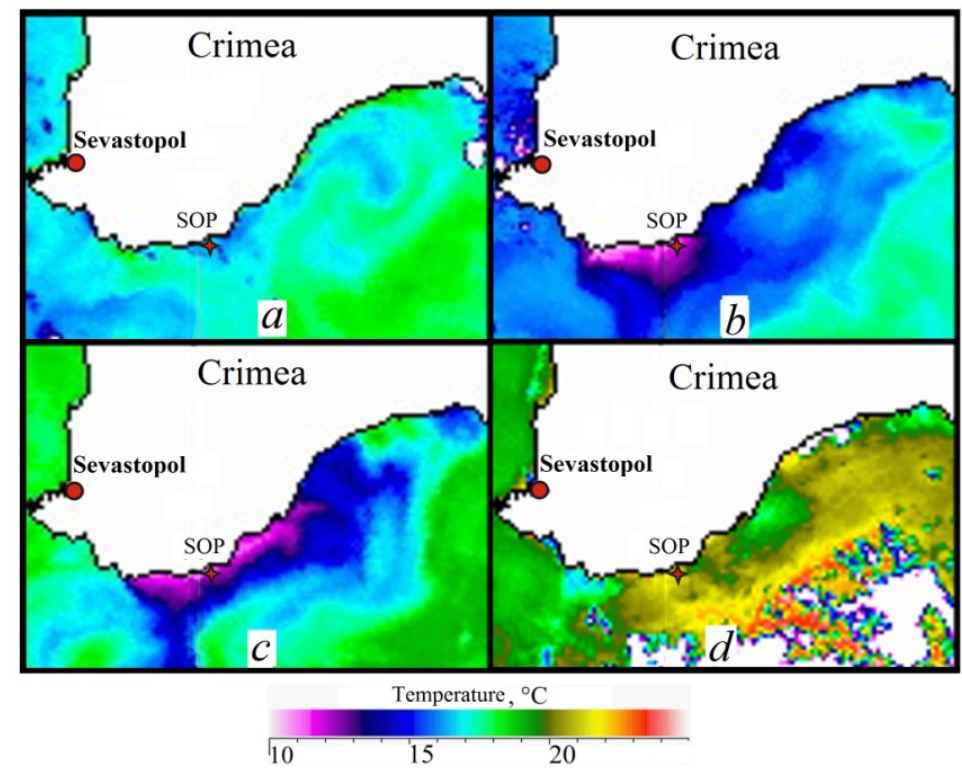

Fig. 3. Water surface temperature change in the SOP area (Katsiveli village) near the Crimean coast in 2010 according to the satellite survey on May $17-a$, May $19-b$, May $26-c$, May $28-d$ [17].

Upwelling termination, according to the data of field STD-probing directly from the SOP, is represented in Fig. 4. When analyzing Fig. 3 and 4 it is evident that by the beginning of the measurement in late May 2010 cold water was no longer displayed at satellite images. Nevertheless, cold water remained in close 
proximity to the surface and continued to affect the exchange processes between water and atmosphere.

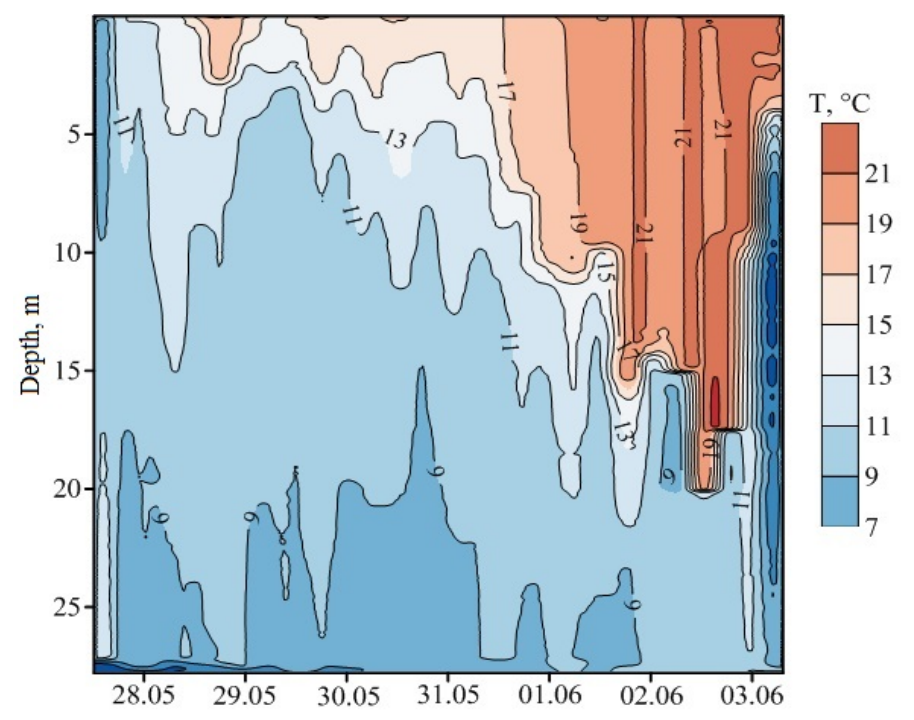

Fig. 4. Temperature variation in the SOP area during the survey in May 2010 according to direct measurement data

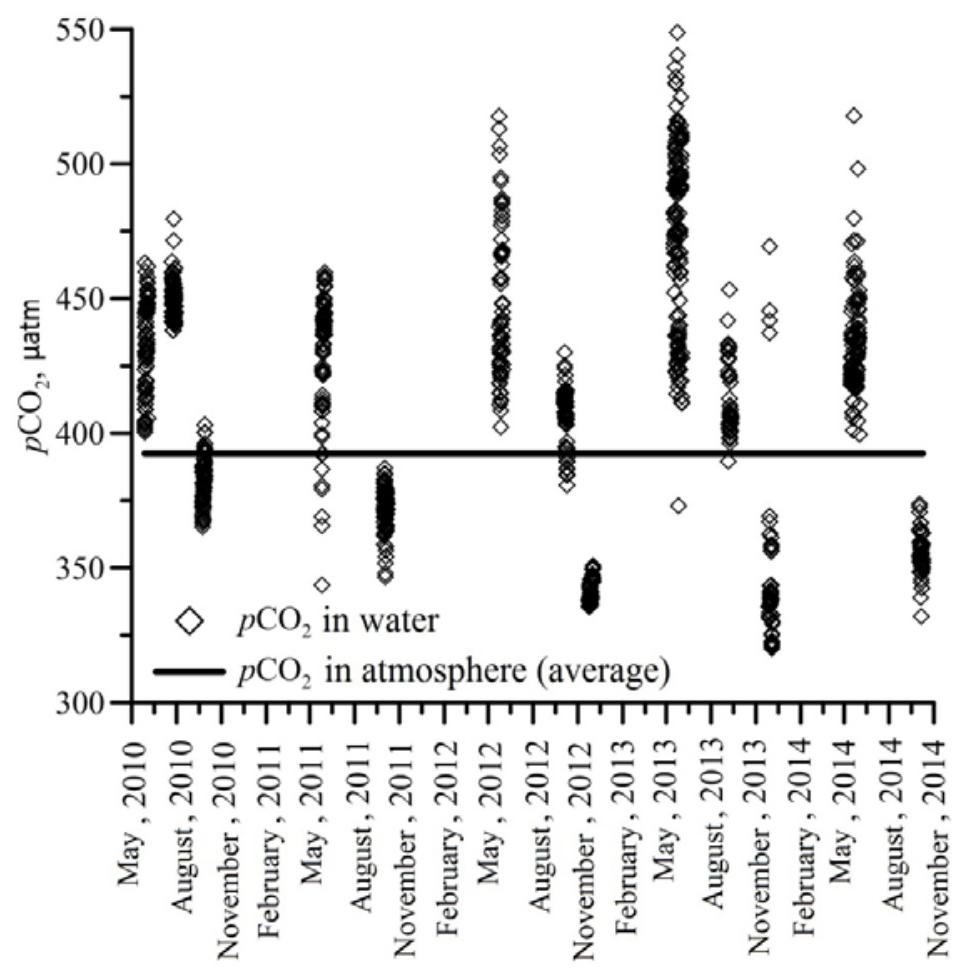

Fig. 5. Variation of carbon dioxide equilibrium partial pressure in the seawater in the SOP area according to the data of direct measurement carried out in 2010 - 2014

PHYSICAL OCEANOGRAPHY NO.1 (2016) 
Further we will consequently discuss the results of expeditionary research, carried out at the SOP by MHI biogeochemistry department in 2009 - 2014 (Fig. 5-8), and will analyze which way the upwelling affected the content of single elements of carbonate system, dissolved oxygen and nutrients.

The carbon dioxide equilibrium partial pressure in the seawater $\left(p \mathrm{CO}_{2}\right)$, obtained during direct measurements at the SOP in different years, are represented in Fig. 5. An average $p \mathrm{CO}_{2}$ value in atmosphere calculated according to direct measurement results, performed at the same time, is given for comparison.

It is evident that intra-annual changes of $p \mathrm{CO}_{2}$ range in the seawater nearsurface layer are characterized by a number of features. The greatest amplitude of $p \mathrm{CO}_{2}$ changes in the seawater was observed during the expeditions, which took place in May. It was manifested especially evident in May 2013. This may arise from $p \mathrm{CO}_{2}$ dependence from water temperature. An intensive spring warming of waters takes place in May, and sufficient temperature fluctuations due to upwelling are characteristic of the same season. Effect of these factors may be considered as one of the main causes of $p \mathrm{CO}_{2}$ sufficient changes during the spring warming.

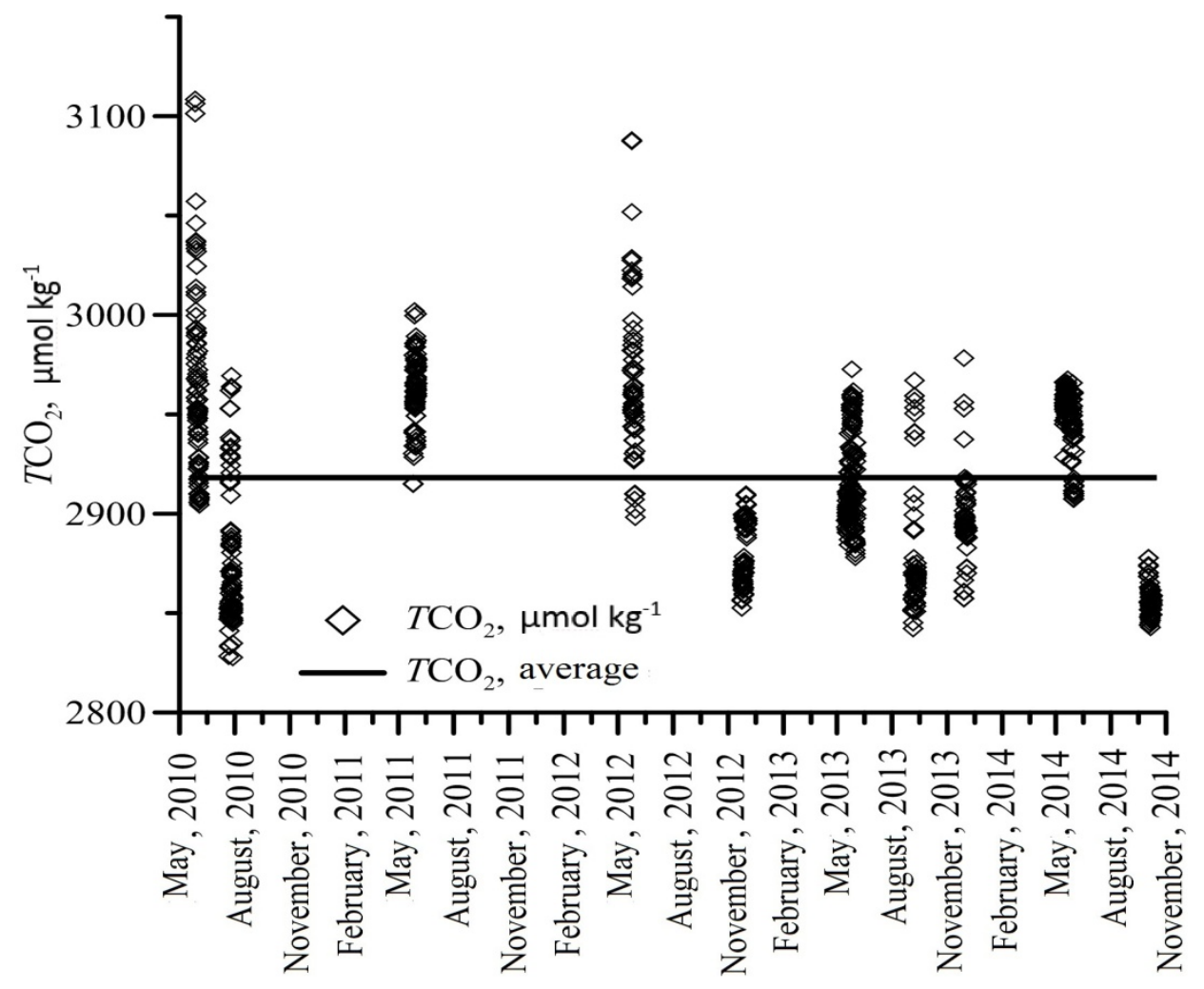

Fig. 6. Variation of seawater dissolved inorganic carbon in the SOP area according to the data of direct measurements performed in 2010 - 2014 


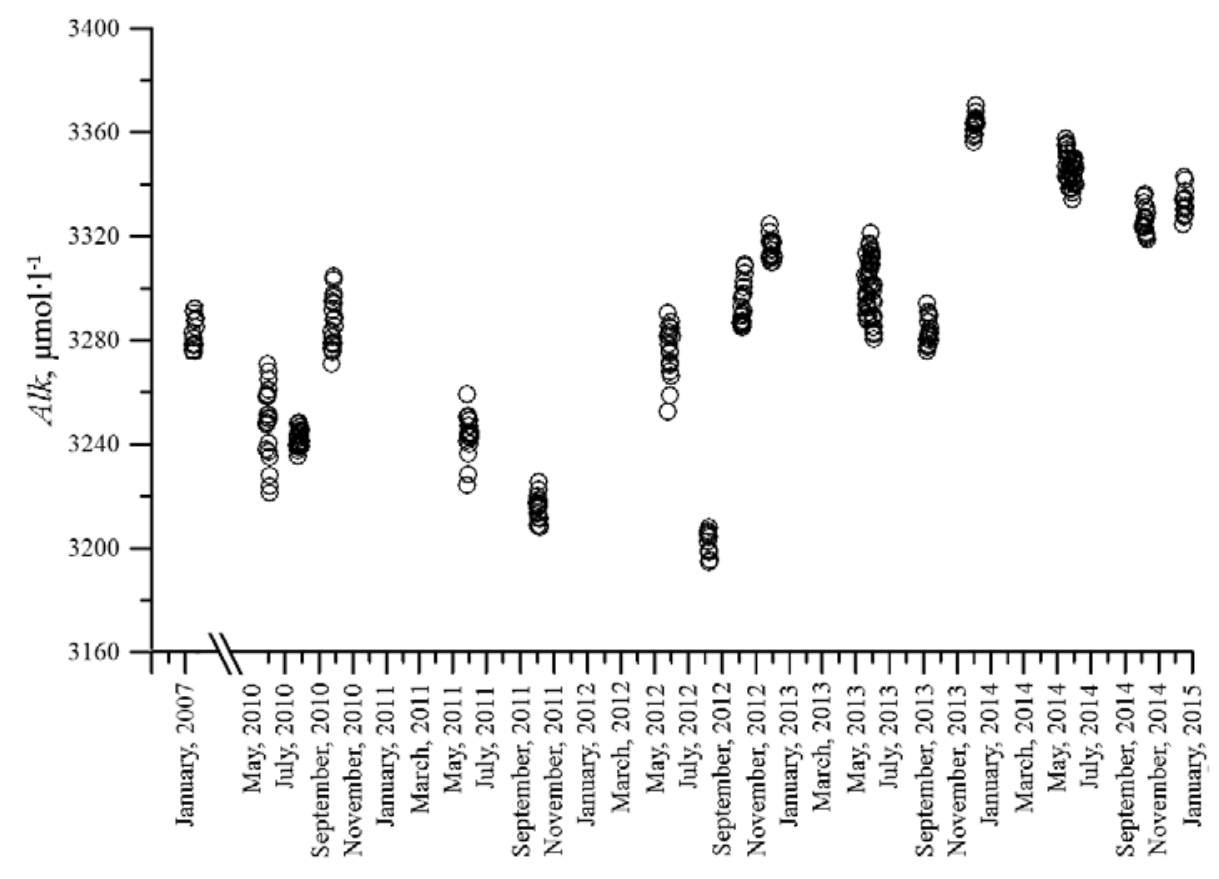

Fig. 7. Variability of seawater total alkalinity in the SOP area according to the data of direct measurements carried out in $2007-2014$
$\bigcirc$ - oxygen, $\mathrm{ml}^{1-1}$;
$\diamond$ - oxygen saturation, $\%$

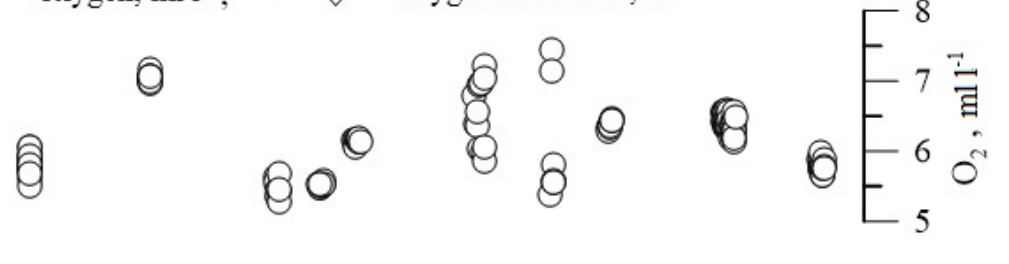

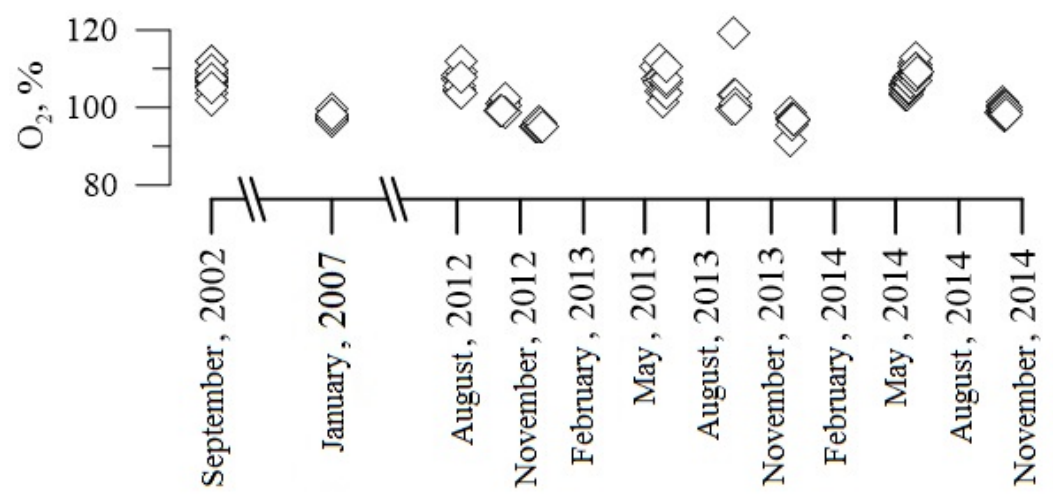

Fig. 8. Content of dissolved oxygen and oxygen saturation in the water surface layer at the SOP area in $2002-2014$ 
In the majority of cases in spring $p \mathrm{CO}_{2}$ values were higher in seawater than in atmosphere, and as a result $\mathrm{CO}_{2}$ evasion was observed. An exception was a survey in May 2011, which was performed after prolonged upwelling. During this survey some cases of equilibrium $p \mathrm{CO}_{2}$ decrease in seawater to the values which were lower than ones in atmosphere. In other cases, in May the equilibrium $p \mathrm{CO}_{2}$ in the water exceeded $p \mathrm{CO}_{2}$ in the atmosphere both under the upwelling conditions and without them.

Stably high $p \mathrm{CO}_{2}$ was observed in the seawater in summer. Thus, in July 2010 during all the survey a stable $\mathrm{CO}_{2}$ evasion to the atmosphere was registered.

The highest inhomogeneity of $p \mathrm{CO}_{2}$ in the water is characteristic of autumn survey results. The surveys were performed during the autumn water cooling in September - October. In most cases of 2010 and in all cases of 2011 and 2014 the $p \mathrm{CO}_{2}$ in the water was lower than the corresponding value for atmosphere. Autumn surveys of 2012 and 2013 were characterized by another pattern: in most cases the $p \mathrm{CO}_{2}$ in the water was higher than the one in atmosphere. A single case when $p \mathrm{CO}_{2}$ in the water was lower than in the atmosphere was registered in September 2013 at the moment of a frontal zone passage, which resulted in a dramatic water temperature decrease.

During the observations carried out in November - December 2012 and 2013 $p \mathrm{CO}_{2}$ values in the water were lower than in the atmosphere. In 2012 such pattern had been observed throughout the survey and in 2013 - during most of observation time. In November 2013 the increased $p \mathrm{CO}_{2}$ values were registered after the storm. It resulted in the fact that surf zone waters were carried in the area of observations.

The concentration of dissolved inorganic carbon $\left(T \mathrm{CO}_{2}\right)$ is one of seawater conservative hydrochemical characteristics. $\mathrm{TCO}_{2}$ variation relative to the average magnitude of this value for all observation time is represented in Fig. 6. Most of observation results performed in May 2010 - 2012 and 2014 exceeded the average value. In summer, and also in cold period of the year (November 2012 and 2013, October 2014) there were observed lower $\mathrm{TCO}_{2}$ concentrations.

The greatest $\mathrm{TCO}_{2}$ change amplitudes were characteristic of surveys performed in May, 2010 and 2012 and also for ones performed in July 2010. TCO fluctuations in May are due to upwelling, and their consequence is an influx of deep waters with higher inorganic carbon content into the surface layer. In summer $T \mathrm{CO}_{2}$ is determined by activity of biota and also by calcium carbonate dissolubility decrease due to water temperature increase.

Seawater total alkalinity values (Alk) obtained in 15 expeditions at the oceanographic platform from 2010 to 2014 as well as during the expedition on board of R/V Experiment in the SOP area in January 2007, are given in Fig. 7. As is evident from the results of five-year research, seawater total alkalinity decreases from the beginning of the year (May), reaching minimum values in August September, and then an intensive increase up to maximum values in winter months takes place.

The greatest spread of Alk (as well as for $p \mathrm{CO}_{2}$ and $T \mathrm{CO}_{2}$ ) during some expeditions is characteristic of surveys performed in May due to intensive changes of seawater hydrologic characteristics in the SOP area in this period. 
An increase of total alkalinity for interannual changes is quite evident. In May, 2010 and 2011 its average values were practically the same, 3248 and $3244 \mu \mathrm{mol} / \mathrm{l}$, correspondingly; then a significant value increase is observed: $3275 \mu \mathrm{mol} / \mathrm{l}$ in 2012, $3300 \mu \mathrm{mol} / \mathrm{l}$ in 2013, $3346 \mu \mathrm{mol} / \mathrm{l}$ in 2014. Similar changes are characteristic of all the seasons except December 2014, when average value of total alkalinity $3333 \mu \mathrm{mol} / \mathrm{l}$ turned out to be somewhat lower in comparison with the analogous $3363 \mu \mathrm{mol} / \mathrm{l}$ value in December 2013.

Concentration of dissolved oxygen in surface layer near the SOP predictably depends on hydrological season (Fig. 8), and it had been changed insufficiently during a single survey. The greatest spread of values was observed in May, 2013 when the surface temperature, warmed up to $20^{\circ} \mathrm{C}$, dramatically decreased due to upwelling. The level of water saturation with oxygen in spring-summer period is stably equal to $110 \%$, and in winter period - to $97-98 \%$ and the upwelling did not affect these values.

Total content of nitrates and nitrites (approximate ratio is 10:1) in surface layer near the SOP during the research time didn't exceed $3 \mu \mathrm{M}$ (Fig. 9). This value was noticeably exceeded only once, on December 1, 2012 after a strong storm in late November (see above).

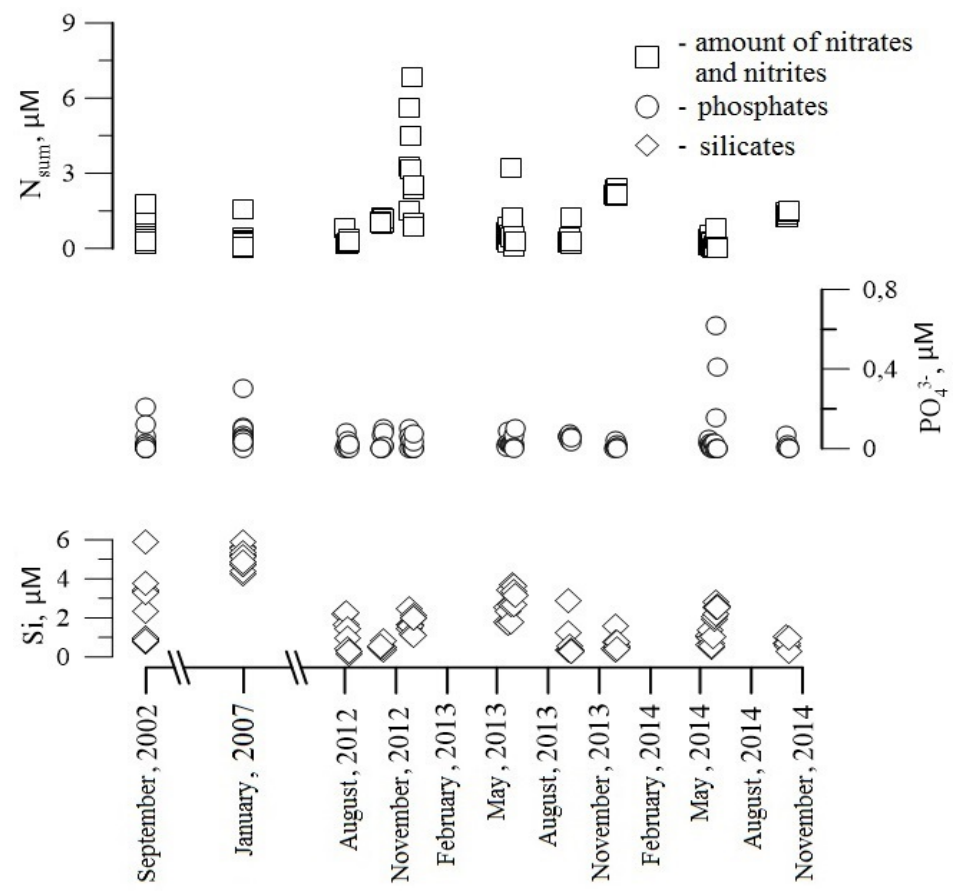

Fig. 9. Content of nitrate and nitrite sum, phosphates and silicic acid in the surface layer near the SOP in $2002-2014$

Phosphate content in surface layer near the SOP over the last 15 years remained, as a rule, at $\sim 0.1 \mu \mathrm{M}$ level. Only in May 2010 a strong upwelling, 
observed in the SOP area, increased a phosphate concentration in $3-4$ times in comparison with "background" values without affecting the content of other biogenic elements. Taken together, these observations confirm the conclusions [12] about the fact that this area is characterized by the absence of phosphate deficiency, which in its turn indicates active dynamic processes that promote a phosphate inflow from the underlying layers of the sea.

Silicic acid content (Fig. 9) in the Blue Bay surface waters over the last 15 years constantly remains at $1-3 \mu \mathrm{M}$ level and does not sufficiently change under the effect of upwelling. Nevertheless, silicic acid concentration considerably changes under the effect of coastal runoff manifestation. Thus, the increased concentrations of this element (for instance, silicic acid concentration above $6 \mu \mathrm{M}$ found out in September 2002 near the estuary of Limenka River, Fig. 2, a) may be used when searching for wastewater sources.

Conclusion. As is evident from the foregoing, the Blue Bay area is a convenient testing ground to carry out synchronous remote and sub-satellite studies of natural oceanographic processes (Fig. 3) and impact of coastal anthropogenic sources of pollution (Fig. 2). Definite advantage of this testing ground is stationary oceanographic platform situated in its south-western part.

Hydrochemical data on water surface layer in the SOP area may be used for study of coastal marine environment "background" state, the effect of intensive natural processes (storms and upwelling) on formation and evolution of surface water hydrochemical and optical composition, gas exchange between the surface waters and the atmosphere, as well as physical, chemical and biological processes on seawater quality.

Two anthropogenic pollution coastal sources in the Blue Bay (their effect on marine environment characteristics may be studied by means of remote and subsatellite synchronous research) complement the capabilities of the given ground for development and approbation of remote methods of marine coastal environment condition study and monitoring.

Acknowledgements. The research was carried out in Marine Hydrophysical Institute RAS under the sponsorship of the Ministry of Education and Sciences of the Russian Federation within the framework of the Federal Target-Oriented Program "Research and Development in Priority Development Directions of the Scientific-Technological Complex in the Russian Federation 2014 - 2020” (unique project code RFMEFI57714X0110).

\section{REFERENCES}

1. Tolmazin, D., 1985, "Changing coastal oceanography of the Black Sea. I: Northwestern Shelf”, Progr. Oceanogr., no. 15, pp. 217-276.

2. Fesyunov, O.E.,Nazarenko, M.F., 1991, “Geomorfologicheskie i ekologicheskie osobennosti zony gipoksii severo-zapadnogo shel'fa Chernogo morya”, Ekologiya morya, iss. 37, pp. 20 26 (in Russian).

3. Aubrey, D., Moncheva, S. \& Demirov, E. [et al.], 1996, "Environmental changes in the Western Black Sea related to anthropogenic and natural conditions”, J. Mar. Syst., no. 7, pp. 411-425. 
4. Feldman, G.C., Murray, J.W. \& Leinen, M.W., 1992, "Use of the coastal zone colour scanner for EqPac Planning”, Oceanography, no. 3, pp. 143-145.

5. Arnone, R.A., Wood, A.M. \& Gould, R.W.Jr., 2004, "The evolution of optical water mass classification”, Oceanography, vol. 17 no. 2, pp. 14-15.

6. Bondur, V.G., Kiler, R.N. \& Starchenkov, S.A., 2006, “Monitoring zagryazneniy pribrezhnykh akvatoriy okeana s ispol'zovaniem mnogospektral'nykh sputnikovykh izobrazheniy vysokogo prostranstvennogo razresheniya [Pollution monitoring of ocean coastal waters using the multispectral satellite images with a high spatial resolution]", Issledovanie Zemli iz kosmosa, no. 6, pp. 42-49 (in Russian).

7. Lavrova, O.Yu., Kostyanoy, A.G., 2011,“Kompleksnyy sputnikovyy monitoring morey Rossii”, IKI RAN, 470 p. (in Russian).

8. Kubryakov, A.A., Stanichny, S.V. \& Zatsepin, A.G. [et al.], 2013, “The propagation of the river waters in the Black and Kara seas from satellite measurements of sea level, salinity and concentration of the chlorophyll A”, Ecological safety of coastal and shelf zones and complex use of shelf resources, iss. 27, pp. 394-398.

9. Garcia, C.A.E., Garcia, V.M.T., 2008, "Variability of chlorophyll- $a$ from ocean color images in the La Plata continental shelf region”, Continent. Shelf Res., 28, pp. 568-578.

10. Zatsepin, G., Kremenetskiy, V.V. \& Stanichny, S.V. [et al.], 2015, "Propagation and transformation of waters of the surface desalinated layer in the Kara Sea”, Oceanology, no. 4, pp. 450-460.

11. “Metody gidrokhimicheskikh issledovaniy okeana”, 1978, Moscow, Nauka, 267 p.

12. Kondratev, S.I., 2009, “Izmeneniya $v$ gidrohimicheskom sostave vod Feodosijskogo zaliva $v$ rezul'tate proniknoveniya azovomorskih vod zimoj 2006 - $2007 \mathrm{gg}$. [Changes in a hydrochemical composition of Feodosia Gulf waters as a result of the Azov Sea water penetration in winter of 2007 - 2008 years]”, Ekologicheskaya bezopasnost' pribrezhnoy $i$ shel'fovoy zon i kompleksnoe ispol'zovanie resursov shel'fa, iss. 18, pp. 30-38 (in Russian).

13. Kondratev, S.I., Zima, V.V. \& Ivanov, V.A. [et al.], 2003, "Nablyudatel'nyy poligon za gidrologicheskimi, gidrokhimicheskimi $i$ gidroopticheskimi kharakteristikami vod $v$ pribrezhnoy zone Yuzhnogo berega Kryma v 2001 - 2002 godakh [Testing ground observations over the hydrological, hydrochemical and hydrooptical water characteristics in the coastal zone of the Southern coast of the Crimea]", Ekologicheskaya bezopasnost' pribrezhnoy i shel'fovoy zon i kompleksnoe ispol'zovanie resursov shel'fa, iss. 7, vol. 1, pp. 49-59 (in Russian).

14. Kondratev, S.I., Lisichenok, A.D. \& Lyashenko, S.V. [et al.], 2003, “Gidrologogidrokhimicheskie i gidroopticheskie kharakteristiki vod Golubogo zaliva (pos. Katsiveli, sentyabr' 2002 g.) [Hydrologic-hydrochemical and hydrooptical characteristics of Blue Bay waters (Katsiveli, September 2002)]”, Ekologicheskaya bezopasnost' pribrezhnoy i shel'fovoy zon i kompleksnoe ispol'zovanie resursov shel'fa, iss. 8, pp. 119-132 (in Russian).

15. Troshchenko, O.A., Kuftarkova, E.A. \& Lisitskaya, E.V. [et al.], 2012, "Rezul'taty kompleksnykh ekologicheskikh issledovaniy na akvatorii midiyno-ustrichnoy fermy (Goluboy zaliv, Krym, Chernoe more) [The results of complex ecological research in the water area of mussel-oyster farm (Blue Bay, the Crimea, the Black Sea)]", Ekologicheskaya bezopasnost pribrezhnoy i shel'fovoy zon i kompleksnoe ispol'zovanie resursov shel'fa, iss. 26, vol. 1, pp. 291-309 (in Russian).

16. Kondratev, S.I., 2012, “Soderzhanie biogennykh elementov i kisloroda $v$ razlichnykh rayonakh ukrainskoy chasti shel'fa Chernogo morya v 2006 - 2010 gg. po dannym ekspeditsionnykh issledovaniy Morskogo gidrofizicheskogo instituta NAN Ukrainy [Nutrient and oxygen content in different regions of Ukranian part of the Black Sea shelf in 2006-2010 according to the field research of Marine Hydrophysical Institute]”, Ekologicheskaya bezopasnost' pribrezhnoy i shel'fovoy zon i kompleksnoe ispol'zovanie resursov shel'fa, iss. 26, vol. 1, pp. 198-211 (in Russian).

17. Khoruzhiy, D.S., Konovalov, S.K., 2014, "Sutochnyy khod i mezhsutochnye izmeneniya soderzhaniya uglekislogo gaza i rastvorennogo neorganicheskogo ugleroda v pribrezhnykh vodakh Chernogo morya" [Diurnal and inter-diurnal variations of carbon dioxide and dissolved inorganic carbon content in the coastal Black Sea waters]”, Morskoy gidrofizicheskiy zhurnal, no. 1, pp. 28-43 (in Russian).

PHYSICAL OCEANOGRAPHY NO.1 (2016) 